\title{
Corruption and Government
}

\author{
SUSAN ROSE-ACKERMAN ${ }^{1}$
}

In countries emerging from civil war with weak governments, bribery demands will be used opportunistically by officials operating under unclear rules that allow them to invent offences or simply to extort funds from ordinary people. Furthermore, many people may engage in illegal activities, such as smuggling or illicit trade in arms, and may need the protection of public authorities to continue to operate. Peacebuilding strategies must avoid triggering vicious spirals. An economy that is jumpstarted by giving monopoly powers to a few prominent people may produce a society that is both lacking in competition and unequal. Although it may be risky and difficult to counter corruption in post-conflict peacebuilding, if the problem is allowed to fester, it can undermine other efforts to create a stable, well-functioning state with popular legitimacy. Care must be taken in starting down the road to reform. Strong leadership from the top is needed that moves towards the goal of a more legitimate and better functioning government and sidelines those who have in the past been using the state as a tool for private gain through threats and intimidation. International assistance can, in principle, help, but it needs to be tailored to avoid exacerbating the underlying problem created by the mixture of corruption and threats of violence from those inside and outside the government.

In a state with very weak institutions, corruption may be a short-term way to hold the system together and prevent violent disintegration. Political leaders buy off powerful private actors with patronage, and powerful private actors, including criminal groups and wealthy business interests, buy off weak politicians with money or promises of future jobs and business ventures.

Unless care is taken, a sharp break with a corrupt status quo can breed instability and violence as those who benefited from the corrupt system struggle to maintain their position. ${ }^{2}$ If conflict prevention and peacebuilding are supported by outside funds from the UN or other institutions, these funds may simply be diverted into the pockets of the powerful, with some trickling down to the mass of the population as a way to keep them quiet. Corruption undermines the reform agenda, and it may be the crutch on which existing leaders rely to maintain power in a chaotic environment.

The goal is a well-functioning system where violence is seldom intertwined with politics and where allegations of corrupt self-dealing lead to a scandal that has political consequences. In such a system revelations of corruption may tip the balance against incumbents implicated in the wrongdoing. By contrast, when democracy is entwined with endemic corruption and where public order is less well established, elections could be an opportunity for violence against opponents, individualized pay-offs to voters, and corrupt pay-offs to politicians.

In countries where threats of violence originate in the private sector, efforts to limit the threat can lead to an increase in violence if the crackdown means that a 
truce between competing gangs or mafias breaks down. This is especially likely if the truce was brokered by corrupt police and government officials. The government's role as a corrupt peacekeeper ends, but it lacks the capacity to be an honest peacekeeper. Police and other law enforcement officials may be unprofessional and poorly paid, and the judiciary may be unable effectively to handle the increased caseload. As private groups fight for control of illegal businesses, such as drugs or smuggling, violence may escalate. The fighting may be mostly between competing criminal groups, but ordinary citizens will be caught in the crossfire, and the provision of government services may suffer.

Similar problems can arise when the groups capable of using violence are not only criminal mafias, but also guerilla groups, paramilitary organizations, or even the nation's regular armed forces. Credible threats of violence can be used to extort pay-offs from ordinary people, businesses and politicians. Kidnapping may develop into a business in which threats to harm the victim generate ransom payments. Groups with the capacity to use violence may combine political and economic strategies.

Inside the government a powerful military may leverage its ability to use force against the civilian government into a device for engaging in illegal businesses. These might include the smuggling and resale of luxury items, the purchase of excessive levels of military equipment as a way to hide kickbacks to top brass, or the use of soldiers as workers in private business ventures.

If such systems are working 'well' from the point of view of the extortionists, there may be little actual violence. Those who are extorted or threatened simply play along and do not rock the boat. Threats of violence can be costly to the growth and democratic legitimacy of a fragile democracy even, or perhaps especially, when little actual violence occurs. A calm status quo does not necessarily indicate that a good governance programme can be easily implemented. Reformers need to ask what is likely to happen if they decide to upset established corrupt relationships or those based on intimidation and fear.

When reform begins, new structures of government and control need to be available quickly or reforms meant to produce good governance and the rule of law can degenerate into a spiral of violence and corruption as citizens seek to deal with the uncertainty generated by reforms. The rule of law is meant to introduce clarity and certainty into economic, social and political relationships. However, if the rhetoric is not matched by a real improvement along these dimensions, the stage is set for chaos and a new set of corrupt incentives.

Although it may be risky and difficult to counter corruption in post-conflict peacebuilding, if the problem is allowed to fester it can undermine other efforts to create a stable, well-functioning state with popular legitimacy. The following section outlines the underlying conditions that create corrupt incentives. The next documents the costs of corruption for ordinary citizens and for state legitimacy. This is followed by a review of empirical work on the causes of corruption, and the next section expands the frame to consider crony capitalism. The article concludes with some reform proposals that may be especially worth considering in weak, post-conflict states. 


\section{Conceptual Underpinnings}

Corruption occurs where private wealth and public power overlap. It represents the illicit use of willingness-to-pay as a decision-making criterion. Frequently, bribes induce officials to take actions that are against the interests of their principals, who may be bureaucratic superiors, politically appointed ministers, or multiple principals such as the general public. Pathologies in the agency/principal relation are at the heart of the corrupt transaction. I differentiate between lowlevel opportunistic pay-offs, on the one hand, and systemic corruption, on the other, which implicates an entire bureaucratic hierarchy, electoral system, or governmental structure from top to bottom. Of course, when corruption reaches the highest levels, it is also likely to prevail lower down as a way of buying the support of petty officials.

In countries emerging from civil war or with very weak governments, lowlevel bribery demands will be used opportunistically by officials operating under unclear rules that allow them to invent offences or simply extort funds from ordinary people. Furthermore, many people may engage in illegal activities such as smuggling or illicit trade in arms, and may need the protection of public authorities to continue to operate. It may be easier to co-opt public officials than to hide from them. Low-level corruption occurs in several generic situations. I consider four.

First, a public benefit may be scarce, and officials may have discretion to assign it to applicants. Then the qualified applicants with the highest willingness to pay and the fewest scruples will get the benefit in a corrupt system. This would seem the least problematic case. The pay-off is a transfer, and the benefits go to those who value it the most in dollar terms. The obvious policy response is to sell the benefit legally. For example, in a post-conflict environment a country might regulate the rebuilding effort by issuing a limited number of construction permits and allocate them legally through sales to the highest bidders. This will ensure that the permits are allocated to those who value them most and will usually be an efficient strategy.

Second, suppose that a benefit is to go only to the qualified. For example, in allocating aid to the victims of the conflict, low-level officials are asked to select needy applicants, but their exercise of discretion cannot be perfectly monitored. The overall supply may be scarce (e.g., temporary housing materials such as tarps or material to repair damaged dwellings) or open-ended (e.g., a programme to buy back 'weapons' where officials must determine whether a broken old rifle should count). In such cases, the officials' discretion permits them to collect bribes and kickbacks from both the qualified and the unqualified. Incentives for pay-offs will depend upon both the ability of superiors to monitor allocations and their own honesty. They will also depend upon the options for the qualified. For example, can they approach another, potentially honest, official?

Third, the bureaucratic process itself may be a source of delay. Incentives for corruption arise as applicants try to get to the head of the queue or manoeuvre through a complex set of requirements. To exploit their corrupt opportunities, officials may create or threaten to create more delays as a means of extracting 
bribes. This may be a particularly effective strategy in the emergency conditions that prevail in the immediate aftermath of violent conflict. For example, in Afghanistan, according to Lorenzo Delesgues and Yama Torabi, 'the transitional administration was characterized by multiple procedures, uncoordinated structures, outdated laws, etc. ... Lack of rationalization and reform transformed the administration into an opaque system at the service of civil servants for predation on state customers'.

Fourth, some government programmes impose costs, for example, tax collection or the possibility of arrest by the police. Officials can then extract pay-offs in return for overlooking the illegal underpayment of taxes or for tolerating illegal activities such as smuggling of both contraband and ordinary goods that are subject to rationing. Even if people are not evading the rules, officials can demand pay-offs in exchange for refraining from arresting them on trumped-up charges.

Low-level corruption can lead to the inefficient and unfair distribution of scarce benefits, undermine the purposes of public programmes, encourage officials to create red tape, increase the cost of doing business and lower state legitimacy. In post-conflict countries trying to attract investment capital and avoid capital flight, corruption can make these efforts difficult, further slowing down the process of economic recovery.

'Grand' corruption shares some features with low-level pay-offs, but it can be more deeply destructive of state functioning - bringing the state to the edge of outright failure and undermining the economy. A post-conflict state that is already fragile can be a breeding ground for high-level malfeasance.

First, a branch of the public sector may be organized as a bribe-generating machine. For example, top police officials may organize large-scale corrupt systems in collaboration with organized crime groups. Tax collection agencies, lotteries, public utilities and regulatory inspectorates can degenerate into corrupt systems managed by high-level officials. Examples include customs collection in Afghanistan and Sierra Leone, and the National Power Authority and the state lottery in Sierra Leone. ${ }^{4}$ This is a particular risk in post-conflict situations where the formal rules are not well known and cannot be enforced, and when the judiciary is weak and corrupt.

Second, a nominal democracy may have a corrupt electoral system. Corruption can undermine limits on spending, get around limits on the types of spending permitted, and subvert controls on the sources of funds. Third, governments regularly contract for major construction projects, allocate natural resource concessions and privatize state-owned firms. High-level politicians can use their influence to collect kickbacks from private firms. If the conflict destroyed a country's infrastructure, this type of corruption will be a particular risk because of the high costs (and the potential for high kickbacks) of the reconstruction effort. All of the post-conflict reconstruction surveys sponsored by the non-governmental organization (NGO) Tiri include examples of these problems. ${ }^{5}$

Some organizations have conflated the varieties of corruption into a single index number for each country. These indices capture the overall scale of the problem but are not much help in directing reform efforts to the most vulnerable 
sectors in post-conflict settings. First, such countries are not included in the indices, and even if they were, a country's ranking before and during the conflict may not be relevant to the new peacetime government. Second, the indices are merely general impressions of the level of corruption that tell one nothing about where it is most pervasive and harmful. Nevertheless, these data do help to document the broad consequences and causes of corruption understood as a proxy for dysfunctional state/society relations built on illicit pay-offs and favouritism. Some of that work is summarized below and particular directions for reform in post-conflict states are suggested.

\section{Consequences of Corruption}

Modern empirical work began with the development of cross-country indices measuring the perception of corruption. The most widely used are compiled by Transparency International (TI), an anti-corruption NGO, and by the World Bank Institute. ${ }^{6}$

Richer countries and those with high growth rates, on average, have less reported corruption and better functioning governments. ${ }^{7}$ However, it is unclear whether low levels of income and growth are a consequence or a cause of corruption. Most likely, the causal arrow runs both ways, creating vicious or virtuous spirals.

High levels of corruption are associated with lower levels of investment and growth, and corruption discourages both capital inflows and foreign direct investment. Thus, Wei found that an increase in the corruption level from relatively clean Singapore to relatively corrupt Mexico is the equivalent of an increase in the tax rate of over 50 percentage points. ${ }^{8}$ Corruption lowers productivity, reduces the effectiveness of industrial policies, and encourages business to operate in the unofficial sector in violation of tax and regulatory laws. According to Lambsdorff, if a country such as Tanzania could achieve the corruption score of the UK, its GDP would increase by more than 20 per cent and net annual per capita capital inflows would increase by 3 per cent of GDP. ${ }^{9}$ Highly corrupt countries tend to under-invest in human capital by spending less on education, to over-invest in public infrastructure relative to private investment, and to have lower levels of environmental quality. ${ }^{10}$ High levels of corruption can produce a more unequal distribution of income and can undermine programmes designed to help the poor. ${ }^{11}$

Corrupt governments lack political legitimacy. ${ }^{12}$ This loss of legitimacy can lead to violence in the form of anti-government riots by people who are frustrated by the venality of public officials. For example, according to Delesgues and Torabi, riots in Afghanistan in May 2006 reflected this lack of trust in government and helped catalyse donors' concerns about corruption and the government illegitimacy that it spawned. ${ }^{13}$

Of course, political supporters of corrupt incumbent governments, not surprisingly, express more positive views of the government. Presumably, this difference depends upon the individualized benefits that flow to these supporters. Surveys carried out in four Latin American countries (El Salvador, Nicaragua, 
Bolivia and Paraguay) in 1998 and 1999 showed that those exposed to corruption had both lower levels of belief in the political system and lower interpersonal trust. ${ }^{14}$ In Nicaragua, respondents were asked if the payment of bribes 'facilitates getting things done in the bureaucracy'. Interestingly, those who agreed that corruption gets things done were less likely to believe in the legitimacy of the political system. ${ }^{15}$ Surveys of firms in countries making a transition from socialism provide complementary findings. Firms with close connections with the government did better than other firms, but countries where such connections were seen as important for business success did worse overall than those where political influence was less closely tied to economic success. ${ }^{16}$

In circumstances of low government legitimacy, citizens try to avoid paying taxes, and firms go underground to hide from the burden of bureaucracy, including attempts to solicit bribes. Using data from the World Values Survey and TI, Eric Uslaner showed that high levels of perceived corruption are associated with high levels of tax evasion, with countries falling into two distinct groups. ${ }^{17}$ His survey data from Romania show that those who believe that one has an obligation to pay taxes have more trust in government. Similarly, Benno Torgler's study of attitudes towards tax evasion in Central and Eastern Europe shows that when individuals perceived that corruption was high, they were less likely to say that people have an obligation to pay taxes. ${ }^{18}$ Thus, one indirect impact of corruption is to persuade people that it is acceptable not to pay taxes because government has been captured by corrupt officials and those who support them. As a consequence, corrupt governments tend to be smaller than more honest governments, everything else being equal. ${ }^{19}$ Thus, in corrupt governments, individual projects are excessively expensive and unproductive, but the overall size of the government is relatively small.

Another way to understand the impact of corrupt officials on ordinary citizens is through the International Crime Victimization Survey (ICVS) compiled by the UN Inter-regional Crime and Justice Research Institute. ${ }^{20}$ Individuals are asked if during the past year any government official had asked them or expected them to pay a bribe in return for services. Naci Mocan used these data, which are available for 49 countries, to show that both personal and country characteristics determine the risk of exposure. ${ }^{21}$ Those of higher wealth and education reported more frequent requests, presumably because they interact more frequently with public officials and have a greater ability to pay. Low levels of reported corruption are related to high levels of institutional quality, uninterrupted democracy and an absence of war. Poor institutional quality leads to both high perceptions of corruption under TI or the World Bank indices and high levels of victimization. The study confirms the claim that corruption is a symptom of underlying institutional weaknesses and a special concern in post-conflict societies. Law enforcement policies that target corruption alone without touching the underlying institutional weaknesses are unlikely to be effective either in changing perceptions or in improving growth. This is an especially important lesson for post-conflict societies.

In diagnostic exercises the World Bank has used household surveys to narrow down anti-corruption efforts to areas of most concern to the population. 
These surveys isolate pressure points where corruption is widespread, but they do not measure the cost of bribery in terms of the inefficient or unfair allocation of public services or burdens. The ICVS does not provide this kind of information either. It simply reports the proportion of people who were asked for a bribe in four areas. The next step in the diagnostic exercise, therefore, should be an estimate of the relative costs of tackling different types of corruption that affect daily life. The answer is likely to be different in a stable country compared with one just emerging from a period of violent confrontation.

\section{Causes of Corruption and Poor Governance}

Given the costs of corruption and poor governance, reformers need to isolate the causes of these phenomena. Cross-country data permit one to obtain a broad overview of the underlying causes of corruption and weak governance. I have already mentioned the role of income and wealth as both a cause and a consequence of corruption. However, that simultaneity often is not well handled in the empirical work. Nevertheless, it seems possible to conclude, first, that poor governance contributes to low growth and to the other harmful outcomes noted above, and that weak underlying economic conditions facilitate corruption. The exception is a very poor country with weak institutions that is so badly off that there is little for anyone to steal.

Some studies found that trade openness and other measures of competitiveness reduce corruption, ${ }^{22}$ suggesting that societies with fewer rents to share are less corrupt. However, once again the causation is unclear; countries that do not favour corrupt firms may be able to establish a policy of open and competitive markets. Lambsdorff, for example, found that weak law and order and insecure property rights encourage corruption, which in turn discourages foreign capital inflows. $^{23}$

Inequality contributes to high levels of corruption. In democracies in particular, inequality facilitates corruption, a result consistent with the state capture variant of corruption. The negative effect of inequality on growth may be the result of its impact on corruption taken as a proxy for government weakness. ${ }^{24}$ Here too the causal arrow goes both ways.

These results for competitiveness and inequality suggest the importance of peacebuilding strategies that avoid vicious spirals. An economy that is jumpstarted by giving monopoly powers to a few prominent people may produce a society that is both lacking in competition and is unequal. Early stage decisions can lock in the power of a small elite whose vested interests then hold back efforts to increase competition and enhance fairness. For example, in Afghanistan President Hamid Karzai 'repeatedly stated that he preferred peace to justice' with the result that the government accommodated elites and ignored ordinary citizens' needs. ${ }^{25}$ This led to a vicious spiral with an estimated 35-50 per cent of aid money wasted. ${ }^{26}$ Similar situations prevailed in Mozambique, Bosnia and Herzegovina and Sierra Leone. ${ }^{27}$

Historical and social factors help explain cross-country differences. For example, Acemoglu et al. used the mortality rates of European settlers as an 
instrument for the type of colonial regime put in place by the imperial power and found that it did a good job of predicting expropriation risk (and corruption levels) at the end of the twentieth century. ${ }^{28}$ La Porta et al. considered legal origin, religion, ethno-linguistic fractionalization, latitude and per capita income as determinants of a range of features of economic, social and political life. ${ }^{29}$ Corruption, as well as other measures of institutional weakness, is worse in countries with higher ethno-linguistic fragmentation, few Protestants and Socialist or French legal origins. ${ }^{30}$

Colonial heritage, legal traditions, religion and geographical factors seem to be associated with corruption and other measures of government dysfunction, but these are not policy variables that present-day reformers can influence. The key issue is whether these historical regularities directly affect government quality or whether they help determine intermediate institutions and attitudes that present-day policies can affect. In La Porta et al., the historical variables are not always significant and become entirely insignificant when they add income and latitude. ${ }^{31}$ Thus, these historical patterns may operate through their impact on underlying institutional structures, not as direct determinants of corruption. If so, that may be good news for reformers in post-conflict settings who seek to create new institutions that facilitate economic growth and high income. ${ }^{32}$ Latitude and history need not be destiny, especially if a conflict has created a space for the creation of a new institutional framework. Less optimistically, the destruction of mediating state institutions can open the way for old ethnic, tribal and religious rivalries to flare up. Witness the difficulties of state building in places such as Bosnia and Herzegovina, Lebanon, Afghanistan and Iraq. ${ }^{33}$

The impact of democracy on corruption is complex. Low levels of corruption are associated both with high levels of economic freedom and with stronger democracies. ${ }^{34}$ Governments with more female participation in politics are less corrupt, and this is consistent with survey evidence suggesting that women are more disapproving of corruption than men. ${ }^{35}$ Within the universe of democracies, features of government structure, such as presidentialism, closed-list proportional representation and federalism, facilitate corruption. ${ }^{36}$ Presidential systems that use proportional representation (PR) to elect their legislature are more corrupt than other types of democracy. Many parliamentary democracies that elect legislatures by plurality rule have a heritage of British colonial rule, and many PR systems had French or Spanish rulers. Present-day levels of freedom also have historical roots. However, if constitutional form, protection of rights, women's rights and electoral institutions are important determinants in and of themselves, then countries have policy levers available even if they cannot change their histories.

\section{Crony Capitalism and the Links between Political and Economic Power}

The World Bank distinguishes between administrative corruption and what its calls 'crony capitalism' or 'state capture'. Research on countries such as Russia, Albania, Indonesia and Malaysia confirms the importance of the distinction, 
and it is likely to be especially relevant in the peacebuilding process. So far, I have mostly been discussing administrative corruption, which includes the use of bribery and favouritism to lower taxes, escape regulations and win procurement contracts. 'State capture' implies that the state itself can be characterized as largely serving the interests of a narrow group of business people and politicians, sometimes with criminal elements mixed in. Even if the group with influence changes when the government changes, most of the citizens are left out. Michael Johnston proposes a taxonomy that includes political systems that manipulate private firms for personal gain. ${ }^{37} \mathrm{He}$ calls this 'power chasing wealth' as opposed to 'wealth chasing power'. The World Bank would probably put both types in the 'state capture' category, but they may have different implications.

In post-conflict settings, case studies of the reconstruction process highlight the way existing elites are frequently able to capture the political and economic benefits of reconstruction. To the extent they can maintain their power bases intact into the post-conflict period, they may be able to position themselves to benefit because other sources of power and institutional constraint are weak. Tiri's Reconstruction National Integrity System Survey provides a number of examples. In Afghanistan several warlords have re-emerged as powerful figures after the fall of the Taliban. According to Delesgues and Torabi, the democratization process gave these warlords 'the opportunity to be integrated as part of the country's political elites'. ${ }^{38}$ In addition to benefiting from being part of the government, regional bosses collect most of the customs revenue. ${ }^{39}$ In Bosnia and Herzegovina, smuggling networks developed during the war that benefited many high officials. These networks remained intact after the war. Reconstruction aid then consolidated the power of these local warlords and ethnic power structures. ${ }^{40}$ As Omer Car and Žarko Papić argue, in the initial phases 'the reconstruction programme was inadvertently and simultaneously aiding the system of governance it was ultimately hoping to do away with'. ${ }^{41}$ In Mozambique both military elites and belligerents were bought off. ${ }^{42}$ Even if such compensation was the price of peace, it needs to be done in ways that do not undermine the state-building project. In Sierra Leone, traditional patterns of patronage and gift giving persist, and political power remains the surest route to wealth in the post-conflict period with its influx of aid. ${ }^{43}$ Case studies of reconstruction in Lebanon show how the need to divide the spoils among the different religious factions undermined efficiency and broad-based accountability. Each politician is only accountable to his or her own group. ${ }^{44}$

Favoured firms may not have secure property rights in the legal sense but may be able to obtain special treatment because of their insider status. ${ }^{45}$ This can promote economic growth, at least for a period of time. Michael Rock and Heidi Bonnett concluded that between 1984 and 1996 the large East Asian countries (China, Indonesia, Korea, Thailand and Japan) were characterized by strong centralized governments with long time horizons that were able to control corrupt networks. ${ }^{46}$

Rulers promoted growth by providing privileges to capitalists in return for kickbacks. These are special cases, however, that do not apply to most 
post-conflict situations. Frequently, reconstruction funds are diverted into the private bank accounts of both politicians and business people, making reconstruction, if it occurs at all, excessively costly. For example, a case study of post-conflict Mozambique notes a 'symbiotic and often corrupt relationship between the authorities and segments of the business sector in the award of contractss ${ }^{47}$ and in the privatization of state-owned assets. ${ }^{48}$

Detailed research has been done on the former communist-governed states in Europe and Central Asia. The World Bank and the European Bank for Reconstruction and Development show that, although administrative corruption is a problem throughout the region, state capture is a particularly serious problem in the countries of the former Soviet Union. In such situations the firms that do the capturing perform well, but overall economic growth suffers. ${ }^{49}$ Fries et al. documented the differences between 'captor' firms with insider status and 'noncaptor' firms. ${ }^{50}$ The former have higher growth rates of fixed capital, revenue and productivity. Slinko et al. obtained similar results using data from the Russian provinces. ${ }^{51}$

If top political figures exploit their position for private gain, the effectiveness of government programmes and the impact of foreign aid and lending suffer. Even if those with good political connections are also good economic managers, there is a long-term risk that they will exploit their dominant positions to squeeze out potential competitors. ${ }^{52}$ This inequality of influence can extend beyond special treatment by the executive and the legislature to include the courts as well.

World Bank researchers define 'crony bias' as the difference between the reported influence of one's own firm and business association, on the one hand, and the influence of those with close ties to political leaders, on the other. This type of bias might be especially likely in post-conflict situations simply because there are no other criteria for making such choices. Alternatively, if the conflict has destroyed existing patterns of influence, it may paradoxically represent an opportunity to recreate the state on a fairer and more democratically legitimate basis. This was Mancur Olson's view in The Rise and Decline of Nations (1982), but it seems a rather optimistic claim even in terms of his own examples that draw heavily on the post-second world war experience. ${ }^{53}$ As Bu-Buakei Jabbi et al. observed, at least in the case of Africa, 'the challenges faced by countries emerging from conflict in Africa ... are completely different from those faced by Europe after the second world war'. ${ }^{54}$ The conflicts erupted after years of one-party rule and require rebuilding or establishing the entire machinery of the state. ${ }^{55}$

If businesses perceive crony bias, this will create problems for the rebuilding effort. In a study using firm-level data from the 2002 Business Environment and Enterprise Performance Survey on former socialist countries, Joel Hellman and Daniel Kaufmann found that firm managers who believe that the state is unduly influenced by a narrow set of 'cronies' are more likely to withhold taxes, pay bribes and avoid using the courts. ${ }^{56}$ These actions then help to keep state institutions weak. Bribery and extortion are mostly a problem for medium-sized businesses. Large dominant firms have close relationships with top political leaders so that mutually beneficial deals are possible. These deals 
are often harmful to the overall growth and prosperity of the country and undermine efforts to establish the legitimacy and trustworthiness of the state.

In the geographically broader World Business Environment Survey of 80 countries there is a marked relationship between the measure of crony bias and survey responses on the size of the unofficial economy and the degree of democratic voice and accountability. A large unofficial economy indicates that the regulatory and taxation powers of government are low and that many firms cannot obtain outside financing because they are off the books. Low levels of voice and accountability suggest that the state is not responsive to its citizens' interests.

\section{Reform Proposals}

Much has been made of the importance of moral leadership from the top, but this is not sufficient. Too much moralizing risks degenerating into empty rhetoric - or worse, witch hunts against political opponents. Policy must address the underlying conditions that create corrupt incentives, or it will have no long-lasting effects.

Some argue that the main cure for corruption is economic growth and that economic growth is furthered by good policies, especially the promotion of education. ${ }^{57}$ However, that claim reflects an overly simple view of the roots of both economic growth and corruption. Particularly in post-conflict situations, policy recommendations that concentrate only on macroeconomic aggregates are pointless. No growth can occur unless institutions are restored to at least a minimal level of competency. Corruption is a symptom indicating that state-society relations are dysfunctional so that they undermine the legitimacy of the state and lead to wasteful public policies. Good policies are unlikely to be chosen or to be carried out effectively without honest institutions.

The ordinary options for institutional reform fall into several broad categories: programme redesign, policies that increase transparency and accountability and, in severe cases, constitutional change. These will be needed in post-conflict state-building, but sometimes they will not be sufficient or even possible because of the remaining levels of violence and the weakness of institutions. I conclude with some proposals that are more directly targeted at post-conflict situations.

The first line of policy response is the redesign of programmes to limit the underlying incentives for pay-offs. This might mean eliminating highly corrupt programmes, but, of course, the state cannot abandon its responsibilities in many areas where corruption is pervasive. One response is to limit official discretion by, for example, streamlining and simplifying regulations, expanding the supply of benefits, making eligibility criteria clear, introducing legal payments for services, giving officials overlapping jurisdictions to give citizens choices, or redesigning systems to limit delays. Reformers should consider whether cleanups in one area would just shift corruption to another part of the government. Programmes may need to be comprehensive to have any impact. In addition, service delivery can be improved by civil service reforms that provide better salaries, improved monitoring, and the use of incentives. 
The second collection of reform strategies focuses on the accountability and transparency of government actions. For example, a freedom-of-information law can give people access to government information, and many government decision-making processes should be open to public scrutiny and participation. Other options to improve accountability are the creation of independent oversight agencies and the use of external and internal benchmarks. Ongoing experiments with grassroots democracy need more study to determine their impact and their transferability to other contexts. ${ }^{58}$ Open government also depends upon a vigorous and free media that can perform a watchdog function. International treaties and organizations such as TI, the World Bank and the UN can help create an environment in which multinationals limit their corrupt activities.

Third, some countries may need to consider more radical reforms in government structure. Democracy is valuable for many reasons, but, taken by itself, is hardly a cure for corruption. Some evidence suggests that presidential systems, above all those using PR in the legislature, may be especially corrupt. ${ }^{59}$ Furthermore, elections are not sufficient. The state must protect civil liberties and establish the rule of law. Rules must be clear and fair and be administered competently and fairly. This implies an honest, professional and independent judiciary, and police and prosecutors who have integrity and competence.

With these more conventional reform options as background, what are the particular factors that must be considered in post-conflict polities? What can international bodies do beyond providing peacekeepers to create a window of opportunity for reform? Each case is different, but the following list provides some general suggestions.

- Seek peace agreements that incorporate measures to limit corruption. This condition, however, will only be valuable if combined with other policies such as those suggested below.

- Anti-corruption and government reform efforts can either set the stage for more reforms or destabilize a fragile equilibrium. ${ }^{60}$ Thus, international peacekeepers may be needed to create a space in which reform can occur. They can only do this, however, if they have the resources to operate effectively. Madelene O'Donnell makes this point by comparing the relatively wellresourced and effective body in Liberia in 2005 with the poorly funded and ineffective force in the Democratic Republic of Congo. ${ }^{61}$

- Pick fights carefully to achieve some early and visible victories and to fit reform programmes to the capacities of the country. Start simply. For example, be sure primary systems of financial control inside agencies are in place before creating secondary bodies such as anti-corruption commissions. ${ }^{62}$

- Do not simply pour in funds without clear checks on their use. One option for international actors is to use trust funds to administer aid programmes with the ultimate goal of turning over programmes to government. For example, the Afghan Reconstruction Trust Fund, operated by the World Bank, channels funds to the government from 24 countries. ${ }^{63}$ In Mozambique, a trust fund for the funding of political parties accepts foreign donations. ${ }^{64}$ 
- International bodies can help buy off and arrange exile for corrupt top leaders. This is superior to incorporating them into the government, ${ }^{65}$ as was done in Afghanistan for warlords with involvement in smuggling and the drug trade. The result has been destabilizing and undermines government legitimacy in the eyes of its citizens. ${ }^{66}$

- Review the training and integrity of law enforcement officers and military personnel. This may involve mass firings followed by universal training opportunities with testing before people are hired or rehired. International aid can help integrate former rank-and-file combatants with financial aid and training.

- Involve ordinary people and local businesses in oversight and participation, and provide safe havens for whistleblowers; but eliminate self-help vigilantes and replace them with the regular police. Oversight can be facilitated by involving established local organizations such as religious bodies. In Afghanistan, for example, one decentralized aid programme uses local mosques as places to display results and financial accounts. ${ }^{67}$

- Restrict the armed forces' and other security services' ability to participate in legal businesses and to engage in illegal businesses and the acceptance of kickbacks. This may need to go along with a one-time buy-out strategy.

- Create bodies both inside government agencies and independent of the executive to administer a freedom-of-information law to audit and monitor government spending. Strengthen the independence of prosecutors and courts. International technical assistance can help for programmes such as the creation of internal financial controls and independent agencies, the development of methods to incorporate public input, or the training of government personnel or media. Stress the creation of systems to monitor public spending and policymaking in general, not just to control the disbursement of aid funds. These institutions are especially important in states such as Mozambique, where political party competition is weak. A case study of that country points out how the overlap of state and party limits accountability and undermines both nominally independent public bodies, such as the judiciary and the Central Office for the Control of Corruption, and civil society groups. ${ }^{68}$ By contrast, a positive case is an effort by an aid-financed NGO to limit payoffs in river transport in the Democratic Republic of Congo. It achieved slow success over time with a mixture of information provision, consultation with local actors, and the introduction of two-way radios. ${ }^{69}$ Another example is the control of education subsidies in post-conflict Sierra Leone. Losses of 45.1 per cent of the total were controlled by hiring an independent auditor to deliver the funds to local schools. This apparently cut loses but was itself expensive, costing the Ministry 12 per cent of the funds dispersed..$^{70}$ More systematic study of interventions by international bodies is needed to see what works and what does not, including the gathering of baseline data so that donors can track programmes as they develop and document progress or setbacks.

- At the global level, international organizations should work to develop stronger international controls on money laundering to make it more difficult for corrupt officials to export their gains. 
Violence and corruption are often deeply intertwined. In such cases, proposals for reform may just produce more violence and corruption in a vicious spiral. Thus, care must be taken in starting down the road to reform. Strong leadership from the top is needed that moves towards the goal of a more legitimate and better functioning government and sidelines those who have in the past been using the state as a tool for private gain through threats and intimidation. International assistance can, in principle, help, but it needs to be tailored to avoid exacerbating the underlying problem created by the mixture of corruption and threats of violence from those inside and outside the government.

\section{NOTES}

1. This contribution draws on Susan Rose-Ackerman, Corruption: A Study in Political Economy, New York: Academic Press, 1978; Corruption and Government: Causes, Consequences and Reform, Cambridge: Cambridge University Press, 1999; 'Governance and Corruption', in Bjørn Lomborg (ed.), Global Crises, Global Solutions, Cambridge: Cambridge University Press, 2004, pp.301-44; (ed.), International Handbook on the Economics of Corruption, Cheltenham: Edward Elgar, 2006. Comprehensive references to the literature in the field can be found in these sources. See also Pranab Bardhan, 'Corruption and Development: A Review of Issues', Journal of Economic Literature, Vol.35, 1997, pp.1320-46; Edward L. Glaeser and Claudia Goldin (eds), Corruption and Reform: Lessons from America's Economic History, Chicago: Chicago University Press/National Bureau of Economic Research, 2006; Jakob Svensson, 'Eight Questions about Corruption', Journal of Economic Perspectives, Vol.19, No.3, 2005, pp.19-42.

2. Philippe Le Billon, 'Buying Peace or Fueling War: The Role of Corruption in Armed Conflicts', Journal of International Development, Vol.15, 2003, pp.413-26.

3. Lorenzo Delesgues and Yama Torabi, Reconstruction National Integrity System Survey Afghanistan, London: Tiri, 2007 (at: www.tiri.org).

4. Ibid., p.23. Bu-Buakei Jabbi, Sonnia-Magha and Salia Kpaka, 'Reconstruction National Integrity System Survey Sierra Leone', London: Tiri, 2007, pp.29-31 (at: www.tiri.org).

5. The studies can be accessed at the Tiri website (at: www.tiri.org).

6. Their websites are: www.transparency.org and www.worldbank.org/wbi/governance. See also the website of the U4 Utstein Anti-corruption Resource Centre (at: www.u4.no).

7. Daniel Kaufmann, 'Rethinking Governance: Empirical Lessons Challenge Orthodoxy', discussion draft, Washington, DC: World Bank, 2003 (at: www.worldbank.org/wbi/governance/pdf/ rethink_gov_standford.pdf).

8. Shang-Jin Wei, 'How Taxing is Corruption on International Investors?', Review of Economics and Statistics, Vol.82, 2000, pp.1-11.

9. Johann Graf Lambsdorff, 'How Corruption Affects Productivity', Kyklos, Vol.56, 2003, pp.457-74.

10. Paolo Mauro, 'The Effects of Corruption on Growth, Investment, and Government Expenditure: A Cross-country Analysis', in Kimberly Ann Elliott (ed.), Corruption and the Global Economy, Washington, DC: Institute for International Economics, 1997, pp.83-108; Daniel Esty and Michael Porter, 'National Environmental Performance Measurements and Determinants', in Esty and Peter K. Cornelius (eds), Environmental Performance Measurement: The Global Report 2001-2002, New York: Oxford University Press, 2002; Vito Tanzi and Hamid Davoodi, 'Corruption, Growth, and Public Finance', in George Abed and Sanjeev Gupta (eds), Governance, Corruption and Economic Performance, Washington, DC: IMF, 2002, pp.197-222.

11. The connection to income distribution may be complex. See Sanjeev Gupta, Hamid Davoodi and Rosa Alonso-Terme, 'Does Corruption Affect Income Inequality?', Economics of Governance, Vol.3, 2002, pp.23-45; and Hongyi Li, Lixin Colin Xu and Heng-Fu Zou, 'Corruption, Income Distribution, and Growth', Economics and Politics, Vol.12, 2000, pp.155-82.

12. Christopher J. Anderson and Yuliya V. Tverdova, 'Corruption, Political Allegiances, and Attitudes toward Government in Contemporary Democracies', American Journal of Political Science, Vol.47, 2003, pp.91-109.

13. Delesgues and Torabi (see n.3 above), p.31. 
14. Mitchell Seligson, 'The Impact of Corruption on Regime Legitimacy: A Comparative Study of Four Latin American Countries', Journal of Politics, Vol.64, 2002, pp.408-33.

15. Ibid., p.429.

16. Steven Fries, Tatiana Lysenko and Saso Polanec, 'The 2002 Business Environment and Enterprise Performance Survey: results from a Survey of 6,100 Firms', Working Paper 84, London: European Bank for Reconstruction and Development, Nov. 2003 (at: www.ebrd.com/pubs/econo/ wp0084.pdf).

17. Eric M. Uslaner, 'Tax Evasion, Trust, and the Strong Arm of the Law', paper at Conference on Tax Evasion, Trust, and State Capacity, University of St Gallen, Switzerland, 17-19 Oct. 2003.

18. Benno Torgler, 'Tax Morale in Central and Eastern European Countries', paper at Conference on Tax Evasion (see n.17 above).

19. Eric Friedman, Simon Johnson, Daniel Kaufmann and Pablo Zoido-Lobaton, 'Dodging the Grabbing Hand: The Determinant of Unofficial Activity in 69 Countries', Journal of Public Economics, Vol.76, 2000, pp.459-93; Simon Johnson, Daniel Kaufmann, John McMillan and Christopher Woodruff, 'Why do Firms Hide? Bribes and Unofficial Activity after Communism', Journal of Public Economics, Vol.76, 2000, pp.495-520.

20. See www.unicri.it/icvs.

21. Naci Mocan, 'What Determines Corruption? International Evidence from Micro Data', Working Paper 10460, Cambridge, MA: National Bureau of Economic Research, April 2004.

22. Alberto Ades and Rafael Di Tella, 'Rents, Competition, and Corruption', American Economic Review, Vol.89, 1999, pp.982-93; Wayne Sandholtz and William Koetzle, 'Accounting for Corruption: Economic Structure, Democracy, and Trade', International Studies Quarterly, Vol.44, 2000, pp.31-50; Charles H. Blake and Christopher G. Martin, 'Combating Corruption: Reexamining the Role of Democracy', paper at the Annual Meeting of the Midwest Political Science Association, Chicago, 25-28 April 2002.

23. Johann Graf Lambsdorff, 'How Corruption Affects Persistent Capital Flows', Economics of Governance, Vol.4, 2003, pp.229-43.

24. Jong-Sun You and Sanjeev Khagram, 'A Comparative Study of Inequality and Corruption', American Sociological Review, Vol.70, 2005, pp.136-57.

25. Delesgues and Torabi (see n.3 above), p.25.

26. Ibid., p.28.

27. Adriano Nuvunga and Marcelo Mosse, 'Reconstruction National Integrity System Survey Mozambique', London: Tiri, 2007, pp.12, 20-21 (at: www.tiri.org); Omer Car and Žarko Papić, 'Reconstruction National Integrity System Survey Bosnia and Herzegovina', Sarajevo: Independent Bureau for Humanitarian Issues Bih, London: Tiri, 2007, p.19 (at: www.tiri.org); Bu-Buakei Jabbi and Kpaka (see n.4 above), p.36.

28. Daron Acemoglu, Simon Johnson and James A. Robinson, 'The Colonial Origins of Comparative Development: An Empirical Investigation', American Economic Review, Vol.91, 2001, pp.1369_ 1401.

29. Rafael La Porta, Florencio Lopez-de-Silanes, Andrej Shleifer and Robert Vishny, 'The Quality of Government', Journal of Law, Economics, and Organization, Vol.15, 1999, pp.222-79.

30. See also Sandholtz and Koetzle (see n.22 above) and Daniel Treisman, 'The Causes of Corruption: A Cross-national Study', Journal of Public Economics, Vol.76, 2000, pp.399-457.

31. La Porta et al. (see n.29 above).

32. Dani Rodrik, 'Growth Strategies', in Philippe Aghion and Steven N. Durlauf (eds), Handbook of Economic Growth, Amsterdam: Elsevier, 2005.

33. Car and Papić (see n.27 above); Delesgues and Torabi (see n.3 above); Nadine Khayat, 'Case Studies Lebanon', London: Tiri, 2007 (at: www.tiri.org).

34. Sandholtz and Koetzle (see n.22 above); Blake and Martin (see n.22 above); Jana Kunicová and Susan Rose-Ackerman, 'Electoral Rules and Constitutional Structures as Constraints on Corruption', British Journal of Political Science, Vol.35, 2005, pp. 573-606.

35. Anand Swamy, Stephen Knack, Young Lee and Omar Azfar, 'Gender and Corruption', Journal of Development Economics, Vol.64, 2001, pp.25-55; Richard C. Crook and James Manor, Democracy and Decentralization in South Asia and West Africa: Participation, Accountability and Performance, Cambridge: Cambridge University Press, 1998, p.42.

36. Kunicová and Rose-Ackerman (see n.34 above); Treisman (see n.30 above). Odd-Helge Fjeldsted provides a literature review on decentralization and corruption that cites studies that contradict the results for federalism found in the sources listed in the text, 'Decentralisation and Corruption: A Review of the Literature', U4 Report, Chr. Michelsen Institute, Bergen, Norway. In any case, 
it is important to distinguish between federalism and explicit policies designed to empower those at the grassroots.

37. Michael Johnston, Syndromes of Corruption: Wealth, Power, and Democracy, Cambridge: Cambridge University Press, 2005.

38. Delesgues and Torabi (see n.3 above), p.20.

39. Ibid., pp.23-4.

40. Car and Papić (see n.27 above), pp.18-19, 27, 67-69.

41. Ibid., p.11.

42. Nuvunga and Mosse (see n.27 above), p.29.

43. Bu-Buakei Jabbi and Kpaka (see n.4 above), p.36.

44. Khayat (see n.33 above), pp.4-5.

45. Joel S. Hellman, Gereint Jones and Daniel Kaufmann, 'Seize the State, Seize the Day: State Capture, Corruption, and Influence in Transition', Journal of Comparative Economics, Vol.3, 2003, pp.751-73.

46. Michael T. Rock and Heidi Bonnett, 'The Comparative Politics of Corruption: Accounting for the East Asian Paradox in Empirical Studies of Corruption, Growth and Investment', World Development, Vol.32, 2004, pp.999-1017.

47. Nuvunga and Mosse (see n.27 above), p.67.

48. Ibid., p.31.

49. Hellman et al. (see n.45 above).

50. Fries et al. (see n.16 above), pp.31-32.

51. Irina Slinko, Evgeny Yakovlev and Ekaterina Zhuravskaya, 'Effects of State Capture: Evidence from Russian Regions', in Janós Kornai and Susan Rose-Ackerman (eds), Building a Trustworthy State in Post-Socialist Societies, New York: Palgrave, 2004, pp.119-32.

52. Daron Acemoglu, 'The Form of Property Rights: Oligarchic vs. Democratic Societies', draft, Department of Economics, MIT, Cambridge, MA, Sept. 2003.

53. Susan Rose-Ackerkman, 'Was Mancur a Maoist? An Essay on Kleptocracy and Political Stability', Economics \& Politics, Vol.15, 2003, pp.163-80. Mancur Olson, The Rise and Decline of Nations, New Haven, CT: Yale University Press, 1982.

54. Bu-Buakei Jabbi et al. (see n.4 above), p.19.

55. Ibid., p.20.

56. Joel S. Hellman and Daniel Kaufmann, 'The Inequality of Influence', in János Kornai and Susan Rose-Ackerman (eds), Building a Trustworthy State in Post-Socialist Transition, New York: Palgrave, 2004, pp.100-118.

57. Edward L. Glaeser, Rafael la Porta, Forencio Lopez-de-Silenes and Andrei Shleifer, 'Do Institutions Cause Growth?', Journal of Economic Growth, Vol.9, No.3, 2004, pp.271-303; Edward L. Glaeser and Raven Saks, 'Corruption in America', Journal of Public Economics, Vol.90, Nos6-7, 2006, pp.1053-72.

58. Rose-Ackerman, 2004 (see n.1 above).

59. Kuniková and Rose-Ackerman (see n.34 above).

60. Le Billon (see n.2 above).

61. Madelene O'Donnell, 'Post-conflict Corruption: A Rule of Law Agenda', in International Peace Academy, Civil War and the Rule of Law, 2006.

62. Ibid.

63. Delesgues and Torabi (see n.3 above), p.17.

64. O'Donnell (see n.61 above).

65. Le Billon (see n.2 above).

66. O’Donnell (see n.61 above); Delesgues and Torabi (see n.3 above).

67. Delesgues and Torabi (see n.3 above), p.17.

68. Nuvunga and Mosse (see n.27 above), pp.74-76, 82.

69. Michael Brown, Philippe Ngwala, Albert Songo and Leonard Wande, 'Combatting Low-level Corruption on Waterways in the Democratic Republic of Congo: Approaches from Bandundu and Equateur Provinces', Working Paper 116, George Washington University Law School, Public Policy and Legal Theory, 2004 (at: www.ssrn.com/abstract=627684).

70. Bu-Buakei Jabbi and Kpaka (see n.4 above), p.100. 